\title{
GESTÃO AMBIENTAL E RESPONSABILIDADE SOCIAL CORPORATIVA: ESTRATÉGIAS DE NEGÓCIO FOCADAS NA REALIDADE BRASILEIRA'
}

Elizângela de Jesus Oliveira² Graziella de Freitas Mulero Matos ${ }^{3}$

Dagmar Silva Pinto de Castro ${ }^{4}$

Recebido em: 06 de fevereiro de 2017 Aprovado em: 02 de maio de 2017 Sistema de Avaliação: Double Blind Review RGD | v. 14 | n. 2 | p. $155-157$ | jul./dez. 2017

Doutor em administração de empresas pela Fundação Getúlio Vargas, o autor Élio Takeshy Tachizawa aborda em seu livro, a gestão ambiental e a responsabilidade social coorporativa voltadas para a realidade brasileira. A obra refere-se ás tendências mundiais das melhorias das empresas diante de um mercado cada vez mais competitivo. Nessa obra, o autor chama atenção para um novo público consumidor que valoriza a sustentabilidade e responsabilidade ambiental como critérios de compra do produto ou serviço. Destarte, o livro é desenvolvido em 20 capítulos que estão divididos em quatro partes - gestão ambiental e responsabilidade social nas organizações; modelo de gestão ambiental e responsabilidade social; estratégias de responsabilidade social e ambiental e outros fatores de influência do modelo. Esta resenha se limita à estratégia de responsabilidade social e ambiental que são assuntos discorridos nos capítulos de números 8 a 12. Dessa forma, o autor inicia seu raciocínio crítico construindo questionamentos com o leitor, acerca das tendências contemporâneas, com relação à implantação de políticas organizacionais de sustentabilidade ambiental e preocupações ecológicas. Nesse contexto, esclarece ainda, sua preocupação quanto à questão socioambiental abordar apenas um discurso passageiro por parte das empresas como forma de diferenciar das demais concorrentes e assim "conquistar" clientes que se posicionam a favor da preservação ambiental. Tachizawa expõe com bastante propriedade que as medidas de preservação ambiental, a princípio, demonstram um ônus para a companhia por provocar um custo alto operacional para a empresa, e que se tornam benefícios verdadeiros a médio e longo prazo. Também tece comentários referentes às principais estratégias de gestão ambiental e de responsabilidade social, de caráter genérico, que normalmente são aplicáveis às organizações. Dentre as estratégias pode-se destacar a expansão dos investimentos em controle ambiental e a imagem ambiental da empresa para fins de marketing, onde o autor da obra ressalva a importância que as empresas atribuem a esses itens como forma de consolidação de suas marcas e

\footnotetext{
${ }^{1}$ TACHIZAWA, E. T. Gestão ambiental e responsabilidade social corporativa: estratégias de negócios focadas na realidade brasileira. São Paulo: Atlas, 2010.

${ }^{2}$ Doutoranda em Administração (Universidade Metodista de Piracicaba/Brasil). E-mail: elizoliveirajesus@ gmail.com.

${ }^{3}$ Graduada em Engenharia de Produção (Centro Universitário Monte Serrat/Brasil). E-mail: graziellamulero@ globomail.com.

${ }^{4}$ Doutorado em Psicologia (Universidade de São Paulo/Brasil). Professora na Universidade Metodista de Piracicaba (Piracicaba/Brasil). Email: dscastro@unimep.br.
} 
aceitação no mercado. Assim, a obra afirma que a implantação da estratégia de gestão ambiental ocorre de forma diferenciada em função do tipo de empresa a ser implantada e dos objetivos a serem alcançados. Empresas que colaboram para o uso coerente dos recursos naturais utilizam posturas de valorização das vocações econômicas comunitárias, respeitando os aspectos socioculturais regionais, ampliando sua credibilidade e as possibilidades de fidelização da clientela, além de abrirem novos nichos de mercado. Em sua obra, o autor Tachizawa aborda ainda três pontos fundamentais para o entendimento do leitor no que concerne ás estratégias organizacionais no mundo contemporâneo. No primeiro ponto, o autor defende a tese do lucro socialmente responsável em harmonia com o aproveitamento racional dos recursos ambientais, através da compatibilidade entre a obtenção de taxas vantajosas de lucratividade e a preservação ambiental. O segundo ponto, contempla o crescimento da consciência ambiental, por meio dos projetos ecologicamente responsáveis, nesse caso, as empresas não poderiam mais se abster às novas demandas de mercado no que diz respeito à sustentabilidade. Por fim, o terceiro ponto reafirma a tendência de que o faturamento das empresas depende cada vez mais do comportamento dos consumidores, que valorizam as organizações certificadas, com selos de qualidade, e principalmente as que estão inseridas na lógica da preservação ambiental.

Ademais, o autor destaca para leitor que a contribuição para a propagação de novos processos de produção sustentáveis e muito mais rentáveis, vem através da adoção de padrões de qualidade entre as organizações e seus fornecedores, onde os padrões exigidos pelo mercado e pelos consumidores são analisados e implantados em toda cadeia produtiva, visto que eles são utilizados como parâmetro para compra e venda dos produtos e matéria-prima. $\mathrm{O}$ autor aborda ainda, um conceito importante para o relacionamento empresa-fornecedor, onde uma das alternativas apresentadas é a sinergia do comprometimento, em que as metas e representatividade são comuns, e tem como resultado a descentralização operacional supervisionada através da terceirização das atividades produtivas. Para o autor da obra, é necessário uma oferta de produtos inovadores, com uma venda focada nos "benefícios", e não apenas na mercadoria em si ou seja, apenas a satisfação das necessidades materiais não garantem a absorção do mercado pelos produtos e serviços. Nesse sentido, diante de um novo perfil de um consumidor que busca qualidade, aliada a preços compatíveis e, sobretudo, o engajamento socioambiental, as empresas cabem ás empresas buscar novos processos de gestão que contemplem aspectos indispensáveis para o cenário atual: preservação ambiental agregada á melhoria da qualidade de vida dos consumidores. Diante disso, deve-se considerar como elementos positivos e valorizados pelos consumidores, a escolha de insumos biodegradáveis, a utilização responsável de energia, a adoção de política de tratamento dos efluentes e resíduos sólidos, aliadas a estratégias de marketing socialmente responsáveis e uma gestão humanizada, que figuram-se como as novas demandas de consumo, combinando funcionalidade e sustentabilidade.

No mundo que vivemos hoje, em constante transformação, em que os consumidores estão sempre conectados, em algumas vezes envolvidos em conflitos políticos, e imersos na desigualdade social; o autor, ainda discorre sobre a responsabilidade social corporativa, destacando a necessidade de sensibilização das organizações para as causas humanitárias. Originalmente a máxima era minimizar custos e maximizar lucros. Diante das novas demandas uma pergunta deve ser respondida: quais são os custos sociais e ambientais dos lucros obtidos pelas organizações? O redimensionamento das estratégias de gestão da produção, bem como a reestruturação das relações entre as empresas e as demandas socioambientais, são questões urgentes e inadiáveis, que devem ser discutidas entre as organizações.

A título de considerações finais e reflexão crítica, o autor da obra resenhada, apresenta um cenário bastante complexo, fluído e inconstante que devem ser enfrentados pelas organizações que queiram alcançar perenidade a longo prazo em seus negócios. É possível verificar que a obra, agrega essas 
tendências atuais no âmbito da responsabilidade social corporativa, apresentando novos conceitos de produção, além de novos produtos e serviços que devem incorporar anseios e expectativas sociais e ambientais como estratégia competitiva. Uma das principais contribuições dos capítulos escolhidos e resenhados é a preocupação do autor em contextualizar ao leitor a realidade em que vive; nesse caso a realidade brasileira. Nesse sentido, o autor enfatiza os problemas a serem enfrentados para se consolidar uma imagem socialmente responsável diante de um cenário brasileiro que é constantemente marcado por desigualdades sociais e crises políticas. A obra é recomendada para discentes das áreas das Ciências Sociais Aplicadas, Humanas, Exatas e Cursos de Engenharias, bem como Cursos Superiores em Tecnologias, pois através de uma linguagem clara e acessível aos leitores contribui para o desenvolvimento da aprendizagem autônoma sobre a implantação de práticas organizacionais voltadas para a valorização dos diferenciais socioambientais. Percebe que a obra avança ao apresentar conceitos de gestão responsáveis dentro da realidade brasileira, apresentando de forma indagadora como que os gestores devem desenvolver técnicas de posicionamento dos produtos e serviços diante de um público consumidor que preza cada vez mais por empresas que investem em práticas de produção sustentáveis. Nesse ponto, considerado um grande avanço da obra, o autor faz questão de chamar atenção para o desenvolvimento crítico do leitor, em relação ás práticas organizacionais "falsas" e de "curto-prazo" de empresas que aparentemente se autodeclaram como sustentáveis. Como dicas para estudos mais aprofundados, sugere-se aos leitores da obra, a realiação de pesquisas de campo com a finalidade de melhor conhecer a realidade da gestão sustentável brasileira. 